ISSN 0103-5150

Fisioter. Mov., Curitiba, v. 29, n. 3, p. 623-633, Jul./Set. 2016

Licenciado sob uma Licença Creative Commons

DOI: http://dx.doi.org.10.1590/1980-5918.029.003.A020

(c)

\title{
Functional development of preterm infants: an integrative literature review
}

\author{
Desenvolvimento funcional de crianças nascidas \\ prematuras: revisão integrativa da literatural
}

\section{Rayla Amaral Lemos, Maria de La Ó Ramallo Veríssimo*}

Escola de Enfermagem da Universidade de São Paulo (EEUSP), São Paulo, Brazil

\begin{abstract}
Introduction: Prematurity is a public health problem. Despite many studies that aim to characterize the effects of premature birth on the various dimensions of child development, there is still little systematic evidence on the functional dimension. Objective: To characterize the functional development of preterm infants in early infancy. Methods: Searches were conducted in PubMed, Science Direct, Scopus, Cochrane, Joana Briggs Institute, Embase, Lilacs and SciELO databases, with the following key words in English and Portuguese and their combinations: preterm, functional performance, functional outcomes, functional limitations, functional skills, activities of daily living and disability. Inclusion criteria were articles published in the last seven years on the investigated subject. Results: The five articles in the sample were organized, analyzed and categorized, reaching up to three empirical categories of analysis: Functional Performance of
\end{abstract}

\footnotetext{
1 Este artigo é um produto da pesquisa “Cuidado de crianças nascidas prematuras: organização das bases teóricas e operacionais e construção de um guia para a promoção do desenvolvimento funcional” financiada pela FAPESP sob processo 2014/087783.
}

*RAL: PhD, e-mail: raylalemos@usp.br

MLORV: PhD, e-mail: mdlorver@usp.br 
Preterm, Cumulative Effects on Functional Development, and Environmental Context and Attitudes of Care. Conclusion: It was concluded that before age 6, children born premature have developmental delays in functional areas of self-care, mobility and social function. Their functional development suffers cumulative effects of various different factors and may be related to care practices and context.

Keywords: Premature. Child Development. Activities of Daily Living. International Classification of Functioning, Disability and Health. Efficiency.

\section{Resumo}

Introdução: A prematuridade é um problema de saúde pública. Apesar dos muitos estudos que buscam caracterizar os efeitos do nascimento prematuro sobre as várias dimensões do desenvolvimento infantil ainda são escassas as evidências sistematizadas sobre a dimensão funcional. Objetivo: Caracterizar o desenvolvimento funcional de crianças nascidas prematuras na primeira infância. Métodos: Foram realizadas buscas nas bases PubMED, Science Direct, Scopus, Cochrane, Joana Briggs, Embase, Scielo e Lilacs, com os seguintes descritores em língua inglesa e portuguesa e suas combinações: preterm, functional performance, functional outcomes, functional limitations, functional skills, activities of daily living e disability. Os critérios de inclusão foram artigos completos, publicados nos últimos sete anos, sobre a temática investigada. Resultados: Os cinco artigos que compuseram a amostra foram organizados, analisados e categorizados, chegando-se a três categorias empíricas de análise: Desempenho Funcional de Prematuros; Efeitos Cumulativos sobre o Desenvolvimento Funcional; Contexto Ambiental e Atitudes de Cuidado. Conclusão: Concluiu-se que menores de 6 anos, nascidos prematuros, apresentam atrasos no desenvolvimento funcional nas áreas de autocuidado, mobilidade e função social. 0 desenvolvimento funcional sofre efeitos cumulativos de vários fatores diferentes e pode estar relacionado às práticas de cuidado e ao contexto.

Palavras-chave: Prematuro. Desenvolvimento Infantil. Atividades Cotidianas. Classificação Internacional de Funcionalidade. Incapacidade e Saúde. Desempenho.

\section{Introduction}

Prematurity is a public health problem worldwide. Every year, 15 million infants are born before completing 37 weeks of gestation, accounting for a prevalence of $11 \%$ in 184 surveyed countries in 2012 (1). In the last decade, prematurity topped the list of causes of neonatal mortality. Brazil is among the 10 countries with the highest rates of preterm births (1), which has increased in recent years $(2,3)$.

Infants who survive premature birth have high rates of short and/or long-term postnatal morbidity (4 - 12). Prematurity has repercussions on child development in its various dimensions, causing losses, delays, changes, or even causing impairments $(9,13$ - 16).

Marlow et al. (17) found motor, visuospatial and sensory function losses in extremely premature infants at age six, showing that these losses compromised cognitive function and could jeopardize school performance. In another study, Marlow et al. (18) showed that extremely premature children at six years of age had the worst results in neurocognitive functions and more disabilities than classmates and in standard normative references. Data from this study shows that $72 \%$ had disabilities in the cognitive domain, $24 \%$ in the neuromotor domain, $10 \%$ presented hearing loss, and $36 \%$ visual loss, such that $80 \%$ of the sample had some minimal, average, or severe disability.

The significant prevalence of morbidity in premature infants assumes more relevance when we consider its effect on functional performance of children born in these conditions. Performance or functional performance is conceptualized as the ability to perform activities of daily living and meet the expectations of their social role (19). Examples of functional activities include: bathing, moving around indoors and outdoors, playing, dressing, eating, personal hygiene, communication, memory of routine activities, and interaction with other people, among others. As for the social role, they include participation in school, in the community and with other children (19). 
Considering functional development, it is important to note that although the preterm performances in specific evaluation tests could be within normal values, there may be losses in functional performance, since different constructs must be evaluated according to their specificities. Functional Performance "Construct" is a broader dimension of child development, considering that it not only concentrates on aspects related to the structure and function of the body, but also focus on the task and the environment in which this task is proposed. Therefore, children born with identical degrees of prematurity may have different performances and/or functional limitations. Similarly, children with the same level of functionality might not have been born with the same conditions.

The growing concern with the functional dimension of child development in the population of preterm infants may be due to a certain extent to the efforts of the World Health Organization (WHO) in proposing and encouraging the use of a biopsychosocial approach model by various professionals and fields of knowledge, as proposed in the International Classification of Functioning, Disability and Health - ICF (20).

ICF offers a comprehensive approach that reflects the interaction between health conditions and contextual factors, considering the functioning of organs or systems and body structures and possible limitations in the execution of activities and social participation in the environment in which the person lives $(21,22)$.

Therefore, understanding the effects of prematurity on functional development of children is another way to establish a conceptual framework and the practice of care consistent with a global trend of deeper and contextualized understanding of health, and its implications in activities and participation, collaborating in a combined effort of this (still) new approach with clinical practice, education, social policies and research.

Although there are many studies focused on the investigation of the effects caused by premature birth, there is still no clear and comprehensive characterization of these effects on the functional dimension of child development in this population, especially early in life, a period of substantial potential for development, but also susceptible to relevant vulnerabilities (23).

The characterization of the functional development of preterm children may expand the understanding of this dimension and the focus on activities in the provision of care, trying to reconcile the assistance to the everyday life in which functional capabilities are expressed, encouraging development, independence and autonomy. Furthermore, it can foster the improvement of services offered, thereby constituting a subsidy for Evidence Based Practice.

In this sense, the objective of this review was to characterize the functional development of preterm children in the early years of life.

\section{Methods}

This is an integrative literature review (24) driven by the guiding question: "How is the functional development of preschool age children who born premature characterized?" This review followed the six steps that compose an Integrative Review according to Souza, Silva and Carvalho (25).

Searches were conducted between August and September 2013, in PubMED, Science Direct, Scopus, Cochrane, Joana Briggs Institute, SciELO, Lilacs and Embase, by using the following descriptors/keywords in English and Portuguese and their combinations: preterm, functional performance, functional outcomes, functional limitations, functional Skills, activities of daily living and disability. The term "preterm" remained the same for all searches. Inclusion criteria were full articles published in English and Portuguese in journals indexed in these databases in the past seven years (2007 - 2013), corresponding to five years after the publication of ICF in Portuguese, relating to issue investigated in this study. Articles investigating different age groups and those replicated in the databases were excluded.

\section{Results}

The total number of queries/articles found by the database were: PubMED [406], Scopus [632], Science Direct [1246], Cochrane [335], Lilacs [5], JBI [0], Scielo [8], Embase [614]. After applying the inclusion and exclusion criteria, five articles were selected for the analysis of the present review: PubMED [1], Scopus [1], Science Direct [2] and Lilacs [1].

Table 1 shows characteristics of the articles as to the origin, year of publication, study type and level of evidence. It can be seen that all articles present a quantitative approach and analytical observational design with a predominance of longitudinal followup studies. 
Table 1 - Descriptive characteristics of the selected studies

\begin{tabular}{|c|c|c|c|c|}
\hline Study & Author/year & Origin & Methodological design & $\begin{array}{l}\text { Level of } \\
\text { evidence* }\end{array}$ \\
\hline $\begin{array}{l}\text { Assessing independency in daily activities in } \\
\text { very preterm children at preschool age }\end{array}$ & Verkerk et al. 2013 & Netherlands & $\begin{array}{c}\text { Quantitative analytical, } \\
\text { observational, longitudinal }\end{array}$ & $2 b$ \\
\hline $\begin{array}{l}\text { Motor and functional development in infants } \\
\text { born preterm and full term: influence of } \\
\text { biological and environmental risk factors }\end{array}$ & $\begin{array}{c}\text { Souza and } \\
\text { Magalhães, } 2012\end{array}$ & Brazil & $\begin{array}{l}\text { Quantitative analytical, } \\
\text { observational, longitudinal, } \\
\text { case-control study }\end{array}$ & $3 b$ \\
\hline $\begin{array}{l}\text { Functional performance according to } \\
\text { gestational age and birth weight of preschool } \\
\text { children born premature or with low weight }\end{array}$ & Lemos et al. 2012 & Brazil & $\begin{array}{l}\text { Quantitative analytical, } \\
\text { observational, transversal }\end{array}$ & $3 b$ \\
\hline $\begin{array}{l}\text { Prediction of motor and functional outcomes } \\
\text { in infants born preterm assessed at term }\end{array}$ & Snider et al. 2009 & Canada & $\begin{array}{l}\text { Analytical, Observational } \\
\text { longitudinal quantitative }\end{array}$ & $2 b$ \\
\hline $\begin{array}{l}\text { Functional Performance of Preterm Children } \\
\text { at Age } 4\end{array}$ & $\begin{array}{l}\text { Sullivan and Msall, } \\
2007\end{array}$ & USA & $\begin{array}{l}\text { Quantitative analytical, } \\
\text { observational, cross-sectional, } \\
\text { case control }\end{array}$ & $3 b$ \\
\hline
\end{tabular}

Table 2 - Methodological design of the articles included in the review

(To be continued)

\begin{tabular}{|c|c|c|c|c|c|}
\hline $\begin{array}{c}\text { Author/ } \\
\text { year }\end{array}$ & Verkerk et al., 2013 & $\begin{array}{c}\text { Souza and } \\
\text { Magalhães, } 2012\end{array}$ & $\begin{array}{l}\text { Lemos et al., } \\
2012\end{array}$ & $\begin{array}{l}\text { Snider et al., } \\
2009\end{array}$ & $\begin{array}{l}\text { Sullivan and Msall, } \\
2007\end{array}$ \\
\hline 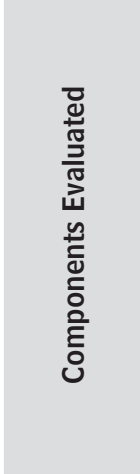 & $\begin{array}{l}\text { Functional performance } \\
\text { and Independence in the } \\
\text { areas of self-care, mobility } \\
\text { and social function } \\
\text { Demographic } \\
\text { characteristics and } \\
\text { perinatal complications } \\
\text { (low weight, septicaemia, } \\
\text { broncodisplasia, etc./ } \\
\text { gender and educational } \\
\text { level of mother) } \\
\text { Motor and mental } \\
\text { development }\end{array}$ & $\begin{array}{l}\text { Functional } \\
\text { performance and } \\
\text { Independence in the } \\
\text { areas of self-care, } \\
\text { mobility and social } \\
\text { function } \\
\text { Quality and quantity } \\
\text { of stimuli and support } \\
\text { of the environmental } \\
\text { context } \\
\text { Motor development }\end{array}$ & $\begin{array}{l}\text { Functional } \\
\text { performance and } \\
\text { Independence in the } \\
\text { areas of self-care, } \\
\text { mobility and social } \\
\text { function } \\
\text { NSE } \\
\text { Degree of prematurity } \\
\text { and low birth weight }\end{array}$ & $\begin{array}{l}\text { Functional } \\
\text { Development } \\
\text { Neurological } \\
\text { dysfunction } \\
\text { Motor control and } \\
\text { organization of } \\
\text { posture in response } \\
\text { to natural interactions } \\
\text { Motor development } \\
\text { Integrity of the } \\
\text { central nervous } \\
\text { System (General } \\
\text { movements) }\end{array}$ & $\begin{array}{l}\text { Functional performance } \\
\text { and independence } \\
\text { in the areas of self- } \\
\text { care, sphincter } \\
\text { control, transfers, } \\
\text { mobility-locomotion, } \\
\text { communication and social } \\
\text { cognition } \\
\text { Motor development } \\
\text { Health status } \\
\text { Demographic } \\
\text { characteristics } \\
\text { Perinatal morbidities }\end{array}$ \\
\hline 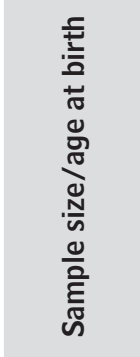 & $\begin{array}{l}N=143 \\
<32 \text { weeks of } \\
\text { gestational age }\end{array}$ & $\begin{array}{l}N=30 \\
\text { Pre-term group } 25 \geq \\
\text { GA } \leq 33 \\
\text { Term group } 37 \geq \mathrm{GA} \\
\leq 41\end{array}$ & $\begin{array}{l}\mathrm{N}=98 \\
<37 \text { weeks of } \\
\text { gestational age } \\
\text { divided into three } \\
\text { groups according } \\
\text { to the degree of } \\
\text { prematurity }\end{array}$ & $\begin{array}{l}\mathrm{N}=95 \\
<32 \text { weeks of } \\
\text { gestational age }\end{array}$ & $\begin{array}{l}\mathrm{N}=155 \\
\text { Pre-term group }<37 \\
\text { weeks of gestational } \\
\text { age divided into three } \\
\text { subgroups according to } \\
\text { the severity of neonatal } \\
\text { complications } \\
\text { Term group } \geq 37 \text { weeks } \\
\text { of gestational age }\end{array}$ \\
\hline 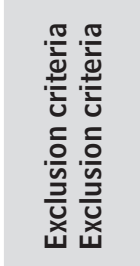 & $\begin{array}{l}\text { Severe congenital } \\
\text { abnormalities, mothers } \\
\text { with a history of illicit } \\
\text { drug use and/or mental or } \\
\text { physical }\end{array}$ & $\begin{array}{l}\text { Signs of neurological } \\
\text { damage, mental } \\
\text { retardation, sensory } \\
\text { impairment, } \\
\text { orthopedic alterations, } \\
\text { need }\end{array}$ & $\begin{array}{l}\text { Congenital } \\
\text { malformations, } \\
\text { chromosomal } \\
\text { alterations, cerebral } \\
\text { palsy }\end{array}$ & $\begin{array}{l}\text { Metabolic, cardiac } \\
\text { chromosomal } \\
\text { disorders; congenital } \\
\text { abnormalities }\end{array}$ & Not reported. \\
\hline 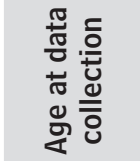 & $\begin{array}{l}3 \text { years and } 8 \text { months } \\
\text { of } \mathrm{CA}\end{array}$ & $\begin{array}{l}12,15 \text { and } 18 \\
\text { months of } C A\end{array}$ & $\begin{array}{l}\text { Pre-school children } \\
\text { between } 2 \text { and } 7 \\
\text { years }\end{array}$ & $\begin{array}{l}40 \text { weeks of } \\
\text { gestational age and } \\
\text { at } 12 \text { months of } C A\end{array}$ & 4 years \\
\hline
\end{tabular}


Table 2 - Methodological design of the articles included in the review

(Conclusion)

\begin{tabular}{|c|c|c|c|c|c|}
\hline $\begin{array}{c}\text { Author/ } \\
\text { year }\end{array}$ & Verkerk et al., 2013 & $\begin{array}{c}\text { Souza and } \\
\text { Magalhães, } 2012\end{array}$ & $\begin{array}{c}\text { Lemos et al., } \\
2012\end{array}$ & $\begin{array}{l}\text { Snider et al., } \\
\quad 2009\end{array}$ & $\begin{array}{l}\text { Sullivan and Msall, } \\
2007\end{array}$ \\
\hline 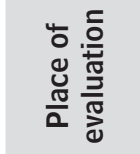 & At home & $\begin{array}{l}\text { Follow-up Clinic and } \\
\text { at home }\end{array}$ & Follow-up Clinic & Not reported & At home \\
\hline 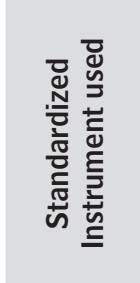 & $\begin{array}{l}\text { PEDI } \\
\text { BSID-II }\end{array}$ & $\begin{array}{l}\text { AIMS } \\
\text { IT-HOME } \\
\text { PDMS-2 } \\
\text { PEDI }\end{array}$ & PEDI & $\begin{array}{l}\text { GMAS } \\
\text { ENNAS } \\
\text { TIMP } \\
\text { AIMS } \\
\text { PDMS-2 } \\
\text { BDI } \\
\text { VABS- DLS }\end{array}$ & $\begin{array}{l}\text { WeeFIM } \\
\text { MSCA } \\
\text { VMI }\end{array}$ \\
\hline
\end{tabular}

Note: Oxford Centre for Evidence-based Medicine Levels of Evidence March 2009.

PEDI- Pediatric Evaluation of Disability Inven-tory, -BSID-II- Bayley Scales of Infant Development, AIMS'Alberta Infant Motor Scale, IT-HOMEInfant/Toddler - Home Observation for Measurement of the Environment, PDMS-2 - Peabody Developmental Motor Scales, NSE- socioeconomic level, ADLs- Activities of daily living, CA- Corrected Age, GMAS- General Movements Assessment Scale; ENNAS- Einstein Neonatal Neurobehavioral Assessment Scale, TIMP- Test of Infant Motor Performance, BDI- Battelle Developmental Inventory, VABS-DLS Vineland Adaptive Behavior Scales- Daily Living Skills domain, MV-Mechanical Ventilation, IPVH- intra-periventricular hemorrage, WeeFIM- Functional Independence Measure for Children, MSCA- McCarthy Scales of Children's Abilities, VMI- Visual Motor Integration.

Table 2 shows methodological design characteristics. All studies used at least one rating scale of child development and considered factors other than prematurity, especially low birth weight and neonatal complications, motor development and other environmental factors, such as family socioeconomic status and educational level of caregivers. The most widely used evaluation instrument for functional development was the Pediatric Evaluation of Disability Inventory (PEDI). In all studies, children with disabilities or serious risk for developing morbidities were excluded and age was corrected during the evaluation according to the degree of prematurity and until the age recommended by literature.

The main results presented by the study are grouped into three broad categories: Preterm Functional Performance, Cumulative Effects on Functional Development and Environmental Context and Attitudes of Care.

\section{Preterm's Functional Performance}

Preterm children have lower scores than the normative population in assessment tests of functional performance and are independent to carry out everyday activities in three main areas of functional development: self-care, mobility and social function (19, $26,27,28)$.
Verkerk et al. (29) argued that $19 \%$ of the sample had at least one inability in one of PEDI domains. In the study by Lemos et al. (27), the sample delay percentage considering the area of functional abilities and independence of PEDI was $25.5 \%$ and $32.7 \%$, respectively. Sullivan and Msall (19) found that preterm children scored lower on functional performance in the areas of self-care, sphincter control, transfers, mobility-locomotion, communication and social cognition. Snider et al. (28) found a wide proportion of delay in functional performance in several areas: mobility, feeding, personal-social, communication, cognitive.

Souza and Magalhães (26) found high percentages of delay in self-care abilities. Lemos et al. (27) showed that lower gestational ages are associated with increased demands for caregiver assistance in this same area. Snider et al. (28) showed that $60 \%$ of the study population had delays in feeding skills, a task related to self-care activities.

Lemos et al. (27) pointed out that the major functional delays in their sample occurred in the received caregiver assistance for mobility, representing greater dependence to perform tasks in this area. Similarly, Verkerk et al. (29) found higher percentages of delay in the abilities of this area. Souza and Magalhães (26) pointed out that preterm infants take longer to acquire walking than full-term infants. Snider et al. (28) described that approximately $70 \%$ of the study 
population did not walk at 12 months of corrected age and point out that functional changes appear early at this same age.

Regarding the abilities and independence in social function, Verkerk et al. (29) highlighted it as the second highest percentage of delay in their sample (8\%), revealing the need for received assistance from the caregiver in this dimension. Similarly, Lemos et al. (27) found this as the second dimension with a large proportion of delays, which occurred both in the abilities (14.3\%) and in Independence (15.3\%) to perform tasks in this area.

\section{Cumulative effects on functional development}

Most studies highlight the existence of the cumulative effects of various environmental and biological factors influencing the functional development of preterm children. Sullivan and Msall (19) state that the functional performance suffers cumulative effects of perinatal complications, low birth weight, of health status and motor development. Moreover, they state that the current health status of a preterm infant impacts their performance of activities of daily living, and that socio-economic level (SEL) influences functional cognition abilities. Snider et al. (28) reported that complications such as duration of mechanical ventilation, presence of intra-periventricular hemorrhage and gender are associated with poor motor and functional results at 12 months, although in their analysis $80 \%$ of the variability of developmental outcomes of premature children at 12 months were due to other different factors of neo/perinatal conditions.

These authors also showed that low scores in motor performance on the Test of Infant Motor Performance (TIMP) scale applied immediately after birth have a predictive value for functional performance. In other words, delays in early motor performance may indicate future functional disabilities. Souza and Magalhães (26) equally highlight the low motor performances by preterm children in the second year of life, as measured by specific instruments and confirmed that environmental factors may enhance the biological risk.

Verkerk et al. (29) pointed out that inability in performing activities of daily living include factors centered on the child and the environment. In their study, low scores in the mental and psychomotor areas, and having non-Dutch mothers were risk factors for functional disability evaluated by PEDI in mobility and social function, respectively. Lemos et al. (27) showed association between the degrees of prematurity and functional performance in children born at lower gestational ages who needed further assistance in self-care. However, they concluded that prematurity and low birth weight on their own does not explain the delays in performing activities of daily living - ADL or independence.

In general, studies indicate that the combination of several factors of biological origin such as neonatal complications, or of environmental origin such as socioeconomic status, have a cumulative effect on the functional development of preterm infants.

\section{Environmental Context and Attitudes of Care}

The results of the analyzed studies indicate that in addition to cumulative effects of biological and environmental factors, the characteristics of the environmental context and attitudes of care may have effects on functional development of children born premature.

Souza and Magalhães (26) evaluated the environmental context of preterm and full term infants, and found that preterm infants have a less stimulating environment in quantity and quality. In this study, the group of preterm infants had lower scores on the HOME involvement scale, showing less physical interaction between mothers and children. The authors discuss the possibility of negligence in the interactive activities and playing with the children, as mothers are more involved and concerned with other aspects such as their health conditions.

Sullivan and Msall (19) note that current health status of preterm children influence the caring behavior of families, warning that the cumulative effect of environmental and biological factors that influence the functional development may also have important implications on how parents care their children and respond to vulnerabilities. It highlighted that preterm parents perceive the readiness for learning functional tasks of their children differently from full term parents. Snider et al. (28) believe that poor functional outcomes in premature children may result from the combination of motor difficulties and parental overprotection; they experience insecurities in caring for their fragile premature baby, or changes related to the adaptation of the child in the home environment. 
All the studies concluded their findings with recommendations. Regarding the care provided by health care support for children born prematurely, the inclusion of assessments are recommended for: functional development $(19,27)$, characteristics and relationships between the environmental context in which this development takes place $(26,28)$, and effects of interventions focused on the enhancement of functional performance (29).

\section{Discussion}

The analyzed studies have evidenced that children born prematurely have significant delays in Functional Development at preschool age. The functional development involves the capacity and independence in performing activities of daily living and a social role expected for this age group. The findings compiled in this review point out that, although age is corrected according to the degree of prematurity and children do not present serious health conditions or disability at birth, functional delays are found in preschool years.

These data imply the reflection that corrected age may not be sufficient to adjust the evaluation of preterm children with respect to functional development, and that the early referral of children with clear signs of alterations or adverse health conditions at birth does not include the entire population with real potential for losses in development, signaling the need for a continuous and detailed approach of all premature children. These results may also mean that preterm children need to be evaluated by specific tests that are based on different normative values for this public, since losses are noticeable even with age correction.

The need for age correction for preterm children is still controversial in the literature. Some authors advocate its use $(15,16)$, while others believe that age correction may overstate preterm performance in comparison to those born full term at two years of age (30). D'Agostino et al. (31) reported that despite the international recommendation for age adjustment in premature infants, most professionals working in primary care do not use it, and that this fact has important implications for the care, such as erroneous detection of delays and early prescriptions. The findings of this review not only corroborate the need for age correction in premature infants, but also underline the need to reassess the adequacy of it to equalize the assessment. We did not find other studies that discuss how satisfactory age correction for premature children.
The concept of "developmental delay" is commonly used by professionals when a child without a specific diagnosis does not perform what is expected for their age group (32). The first years of life are critical for child development, so that functional delays at this stage may have an impact regarding development potential and its expression in the daily activities and social participation. Activity limitations can be understood as the difficulties that individuals can have in performing activities, and participation restrictions as problems faced while involved in a real life situation (33). This could mean greater need for assistance at home, at school and in the community, as well as less autonomy and ultimately, an impairing children's quality of life.

The reviewed studies have shown functional impairment in three main dimensions: self-care, mobility and social function. Considering the use of PEDI in most of the analyzed studies, we can infer which activities are included and evaluated in each area of functional development. Self-care include activities such as feeding (eating different textures, ability to use utensils to eat and drink), hygiene (oral, hair, nose, face, hands and body), getting dressed (upper and lower body, handling of buttons, zippers, and footwear) and sphincter control/toileting tasks. Mobility activities include: transfer (in the bathroom and shower, to the chair, bed, and means of transport), transport (both indoor and outdoor environments with distances, speeds and different surfaces) and use of stairs (going up and down). The social function involves: understanding and expression of language, problem solving, interactive social games (with adults and children), playing, self-information, orientation of time, household tasks, self-protection and community function (34).

Most preterm infants need to remain under care in Neonatal Intensive Care Units - NICU. In these units, the main focus of assistance is to keep the child's stability and treatment of common systemic and/or structural complications with a focus on management of equipment and supporting technologies $(35,36)$. Thus, restriction of movement, maintaining positions and deprivation of stimulating environments for development in the immediate neonatal period can change the pace of subsequent acquisitions of functional self-care abilities such as holding their bottle, of mobility such as rolling on the bed, and of social function such as recognizing their own name; thus, creating delays that are not always overcome in the near future, or even in early childhood. 
Similarly, one can judge that the excess of sensory stimuli in the NICU environment could create an adaptation or aversion to these types of stimuli (35), leading to limitations of activity or participation restrictions related to operational difficulties, tolerance to be touched and later in interaction with adults and children, playing, self-protection, feeding, hygiene, getting dressed, and other functional activities in the dimensions of self-care, mobility and social function.

Also, the use of mechanical ventilation (MV) in neonatal period is very common among preterm infants (37), sometimes requiring intubation and being deprived of breastfeeding. Prolonged use of MV may lead to the establishment of other respiratory illnesses $(37,38)$, in addition to low motor performance (38), probably due to limiting the variation in positioning the child in their spontaneous movement and postural adjustments. These early experiences can have repercussions on their functional abilities, especially in the areas of self-care and mobility due to possible injury in the upper airway, underdevelopment of musculoskeletal, neurological and sensory systems, whose integrity is essential for execution of activities in these areas.

From these previous aforementioned discussions, we can learn that neonatal experiences and length of NICU stay are important for functional development. Functional delays can already be perceived in the first 12 months (28), and can be seen in the delay in the acquisition of independent walking. Confirming the results of studies in this review, Restiffe and Guerpelli (39) found that preterm infants walk a month later than term infants, being predictors for this acquisition the weight and height of birth as well as length of stay in the NICU.

Additionally, studies show that the functional development of a preterm infant is not the result of the influence of a single factor, but it suffers from the cumulative effects of factors of various elements, such as low birth weight and socioeconomic status. This is probably due to the complexity of the functional activities of daily living which concentrate various competencies produced by integrity and development of multiple domains. For example, the self-care functional activity of brushing teeth implies that the child has motor coordination, dexterity, knows the tools needed for this activity (toothbrush and toothpaste), knows what they are for, how to handle them, knows how to perform a task with several steps, has the ability to rinse and not swallow, and so on, outlining a motor and cognitive repertoire working jointly and harmoniously. The same reasoning applies to all functional abilities in all areas. These findings call upon the comprehensive care and the systematic monitoring of premature infants.

The reported effects of current health conditions regarding functional performance reflect a reality that we can consider common in preterm and full-term children. Being sick is a limiting factor for implementing activities of daily living. However, for premature infants we must take into account two factors: the first is that of their greater biological vulnerability, arising from the initial immune system weakness, the possible absence of breastfeeding, and the overall systemic immaturity that would make them potentially prone to developing conditions of adverse health, to diseases and to hospitalizations. In addition, the attitudes of care should also be considered for children who have adverse health conditions in the present, since they can refer to past experiences that were common from the neonatal period; fear, anxiety, uncertainty and loss (40), and in this way, parents/caregivers may be highly protective and limiting functional development.

Although the amount of evidence on the relationship between the context and attitudes of care on functional development is restricted, they cannot be ignored when analyzing that this is expressed by the performance of daily living activities, independence and social roles. Sitting in an adult chair, for example, can be a different task to be performed depending on type of mobility available in the child's home in terms of form and structure, if there is this kind of furniture at home or not, and even if the caregiver considers it prudent and allows the child to climb onto an adult chair. Along the same lines, climbing up the stairs with regular steps in the house has different requirements than uneven steps, and although the stairs are identical, it is possible that caregivers of children of the same age consider performing this task for their children differently, allowing them to perform this activity or instead carrying them up. Despite the functional ability being the same, the capacity to implement might have variations in different contexts and with different attitudes of care that will enhance or limit the functional development of the child. There are reports of different performance levels between preterm infants of different socioeconomic levels and from the overprotection of their parents (41). 
Thus, considering the context and providing tools for parents for care practices in relation to the real potential of their children according to their age, health condition and history of prematurity may collaborate to maximize functional development and perhaps reduce the effects of adverse conditions of multiple risk factors.

\section{Conclusion}

This review has shown that children exhibit delays in functional development, particularly in three areas: self-care, mobility and social function, even despite age correction. Cumulative effects of biological and environmental factors interact with prematurity and affect functional development of preterm infants in early childhood. Functional development may be related to care practices and the context in which the subjects are inserted.

Thus, monitoring of these children should include all these aspects, in order to provide support for the creation of more favorable conditions and to limit the harmful effects of prematurity on development. It is recommended that future studies qualitatively explore delays in the functional development of premature infants, as well as effective strategies to promote their development, aiming at a more qualified and specific assistance to the demands of this population.

The scarcity of articles available in the literature on the subject in question and restricted levels of the evidence included in this review, even despite the methodological consistency thereof, can be mentioned as study limitations. This fact underlines the need to deepen the knowledge in this area.

\section{References}

1. Kinney MV, Lawn JE, Howson CP, Belizan J. 15 million preterm births annually: what has changed this year? Reprod Health. 2012;9:28.

2. Victora CG, Aquino EML, Leal MC, Monteiro CA, Barros FC, Szwarcwald CL. Maternal and child health in Brazil: progress and challenges. Health in Brazil 2. Lancet. 2011;377(9780):1863-76.

3. Silveira MF, Santos IS, Barros AJD, Matijasevich A, Barros FC, Victora CG. Aumento da prematuridade no Brasil: revisão de estudos de base populacional. Rev Saude Publica. 2008;42(5):957-64. Portuguese.
4. Goldenberg RL, Culhane JF, Iams JD, Romero R. Epidemiology and causes of preterm birth. Lancet. 2008;371:75-84.

5. Drotar D, Hack M, Taylor G, Schluchter M, Andreias L, Klein N. The Impact of Extremely Low Birth Weight on the Families of School-Aged Children. Pediatrics. 2006;117(6):2006-13

6. Khan NZ, Muslima H, Parveen M, Bhattacharya M, Begum N, Chowdhury S, et al. Neurodevelopmental outcomes of preterm infants in Bangladesh. Pediatrics. 2006;118(1): 280-9.

7. Manacero S, Nunes ML. Evaluation of motor performance of preterm newborns during the first months of life using the Alberta Infant Motor Scale (AIMS). J Pediatr. 2008;84(1):53-9.

8. Roberts G, Howard K, Spittle AJ, Brown NC, Anderson PJ, Doyle LW. Rates of early intervention services in very preterm children with developmental disabilities at age 2 years. J Paediatr Child Health. 2008;44:276-80.

9. Silva ES, Nunes ML. The influence of gestacional age and birth weight in the clinical assesment of the muscle tone of healthy term and preterm newborns. Arq Neuropsiquiatr. 2005;63(4):956-62.

10. Nair MK, Chacko DS, Paul MK, Nair L, George B, Kumar GS. Low birthweight babies- outcome at 13 years. Indian Pediatr. 2009;46 Suppl:s71-4.

11. Verrips E, Vogels T, Saigal S, Wolke D, Meyer R, Hoult L, et al. Health-Related Quality of Life for Extremely Low Birth Weight Adolescents in Canada, Germany, and the Netherlands. Pediatrics. 2008;122(3):556-61.

12. Zwicker JG, Harris SR. Quality of Life of Formerly Preterm and Very Low Birth Weight Infants From Preschool Age to Adulthood: A Systematic Review. Pediatrics. 2008;121(2): 366-76.

13. Abdel-Latif ME, Bajuk B, Ward M, Oei JL, Badawi $\mathrm{N}$; NSW and ACT Neonatal Intensive Care Units Audit Group. Neurodevelopmental outcomes of extremely premature infants conceived after assisted conception: a population based cohort study. Arch Dis Child Fetal Neonatal Ed. 2013;98(3):F205-11.

14. Resegue R, Puccini RF, Silva EMK. Risk factors associated with developemental abnormalities among hight-risk children attendend at a multidisciplinary clinic. Sao Paulo Med J. 2008;126(1):4-10. 
15. Restiffe AP, Gherpelli JLD. Comparison of chronological and corrected ages in the gross motor assesment of low-risk preterm infants during the first year of life. Arq Neuropsiquiatr. 2006;64(2B):418-25.

16. Rugolo LMSS. Crescimento e desenvolvimento a longo prazo do prematuro extremo. JPediatr. 2005;81(1):1019. Portuguese.

17. Marlow N, Hennessy EM, Bracewell MA, Wolke D. Motor and Executive Function at 6 Years of Age After Extremely Preterm Birth. Pediatrics. 2007;120(4):793-804.

18. Marlow N, Wolke D, Bracewell MA, Muthanna S. Neurologic and Developmental Disability at Six Years of Age after Extremely Preterm Birth. N Engl J Med. 2005;352(1):9-19.

19. Sullivan MC, Msall ME. Functional Performance of Preterm Children at Age 4. J Pediatr Nurs. 2007;22(4):297-309.

20. Organização Mundial da Saúde. CIF: Classificação Internacional de Funcionalidade, Incapacidade e Saúde. Trad. do Centro Colaborador da Organização Mundial da Saúde para a Família de Classificações Internacionais. São Paulo: EDUSP; 2003.Portuguese.

21. Farias N, Buchalla CM. A classificação internacional de funcionalidade, incapacidade e saúde da organização mundial da saúde: conceitos, usos e perspectivas. Rev Bras Epidemiol. 2005;8(2):187-93. Portuguese.

22. Rosenbaum P, Stewart D. The World Health Organization International Classification of Functioning, Disability, and Health: A Model to Guide Clinical Thinking, Practice and Research in the Field of Cerebral Palsy. Semin Pediatr Neurol. 2004;11(1):5-10.

23. Brazelton TB, Greespan SI. As necessidades essenciais das crianças. 0 que toda criança precisa para crescer, aprender e se desenvolver. Porto Alegre (Brazil): Artmed; 2002. Portuguese.

24. Mendes KDS, Silveira RCCP, Galvão CM. Revisão integrativa: método de pesquisa para a incorporação de evidências na saúde e na enfermagem. Texto Contexto - Enferm. 2008;17(4):758-64. Portuguese.

25. Souza MT, Silva MD, Carvalho R. Revisão integrativa: o que é e como fazer. Einstein. 2010;(1 Pt 1):1026. Portuguese.
26. Souza ES, Magalhães LC. Desenvolvimento motor e funcional em crianças nascidas pré-termo e a termo: influência de fatores de risco biológico e ambiental. Rev Paul Pediatr. 2012;30(4):462-70. Portuguese.

27. Lemos RA, Fronio JS, Ribeiro LC, Demarchi R, Silva J, Neves LAT. Functional performance according to gestational age and birth weight of preschool children born premature or with low weight. Rev. bras. crescimento desenvolv. hum. 2012;22:17-26.

28. Snider L, Majnemer A, Mazer B, Campbell S, Bos AF. Prediction of motor and functional outcomes in infants born preterm assessed at term. Pediatr Phys Ther. 2009;21(1):2-11.

29. Verkerk G, Jeukens-Visser M, van Wassenaer-Leemhuis A, Koldewijn K, Kok J, Nollet F. Assessing independency in daily activities in very preterm children at preschool age. Res Dev Disabil. 2013;34(7):2085-91.

30. Mancini MC, Teixeira S, Araújo LG, Paixão ML, Magalhães LC, Coelho ZAC, et al. Estudo do desenvolvimento da função motora aos 8 e 12 meses de idade em criança nascidas pré-termo e a termo. Arq Neuropsiquiatr. 2002;60(4):974-80. Portuguese.

31. D'Agostino JA, Gerdes M, Hoffman C, Manning ML, Phalen A, Bernbaum J. Provider use of corrected age during health supervision visits for premature infants. J Pediatr Health Care. 2013;27(3):172-9.

32. Silva EM, Albuquerque CP. Atraso do desenvolvimento: A imprecisão de um termo. Psicol Saude Doencas. 2011;12(1):19-39. Portuguese.

33. Vale MC. Classificação Internacional de Funcionalidade (CIF): conceitos, reconceitos e paradigmas. Contributo de um construto para o percurso real em meio natural de vida. Acta Pediatr Port. 2009;40(5):22936. Portuguese.

34. Mancini MC. Inventário de Avaliação Pediátrica de Disfunção: versão brasileira. Belo Horizonte (Brazil): Laboratório de atividade e desenvolvimento infantil, Departamento de Terapia Ocupacional, Universidade Federal de Minas Gerais; 2005. Portuguese.

35. Silva LJ, Silva LR, Cristoffell MM. Tecnologia e humanização na Unidade de terapia intensiva neonatal: reflexões no contexto do processo saúde doença. Rev Esc Enferm USP. 2009;43(3):684-9. Portuguese. 
36. Gaiva MAM. O cuidar em unidades de cuidados intensivos neonatais: em busca de um cuidado ético e humanizado. Cogitare Enferm. 2006;11(1):616. Portuguese.

37. Lemos RA, Frônio JS, Neves LAT, Ribeiro LC. Estudo da Prevalência de morbidades e complicações neonatais segundo o peso ao nascimento e a idade gestacional em lactentes de um serviço de follow-up. Rev APS. 2010;13(3):277-90. Portuguese.

38. Araújo AT, Eickmann SH, Coutinho SB. Fatores associados ao atraso do desenvolvimento motor de crianças prematuras internadas em unidade de neonatologia. Rev Bras Saude Matern Infant. 2013;13(2):11928. Portuguese.

39. Restiffe AP, Gherpelli JL. Differences in walking attainment ages between low-risk preterm and healthy fullterm infants. Arq Neuro-Psiquiatr. 2012;70(8):593-8.

40. Carvalho JBL, Araújo ACPF, Costa ICC, Brito RS, Souza NL. Representação social de pais sobre o filho prematuro na Unidade de Terapia Intensiva Neonatal. Rev Bras Enferm. 2009;62(5):34-8. Portuguese.

41. Mancini, MC, Megale L, Brandão MB, Melo APP, Sampaio RF. Efeito moderador do risco social na relação entre risco biológico e desempenho funcional infantil. Rev Bras Saude Matern Infant. 2004;4(1):2534. Portuguese.

Received in $12 / 12 / 2013$

Recebido em 12/12/2013

Approved in 09/03/2015

Aprovado em 03/09/2015 
